\title{
Necrotizing Fungal Infection Following Penile Prosthesis Implantation: A Case Report
}

\section{Penil Protez Implantasyonu Sonrası Nekrotizan Mantar Enfeksiyonu: Olgu Sunumu}

\author{
Mehmet Gökhan Çulha, Erkan Erkan, Uğur Yücetaş, Mustafa Kadıhasanoğlu, Mahmut Gökhan Toktaş \\ University of Health Sciences, istanbul Training and Research Hospital, Clinic of Urology, Istanbul, Turkiye
}

\begin{abstract}
Infection is one of the most devastating complications of penile prosthesis implantation. Although the infection prevalence have decreased owing to new technologies and growing surgical experience, it is still a troublesome situation. We present a 50-year-old male patient who had necrotizing fungal infection after penile prosthesis implantation caused by Trichosporon asahii.
\end{abstract}

Keywords: Fungi, infection, necrosis, penile prosthesis, Trichosporon asahii

Öz

Enfeksiyon, penil protez implantasyonunun en tahrip edici komplikasyonudur. Cerrahi deneyimin gelişmesi ve yeni teknolojiler sayesinde enfeksiyon prevalansı düşmekte olmasına rağmen, halen sıkıntılı bir durum olmaya devam etmektedir. Penil protez implantasyonu sonrası "Trichosporon asahii"nin sebep olduğu nekrotizan mantar enfeksiyonu gelişen 50 yaşında erkek olguyu sunmaktayız.

Anahtar Kelimeler: Mantar, enfeksiyon, nekroz, penil protez, Trichosporon asahii

\section{Introduction}

Penile prosthesis implantation is an important treatment option for severe erectile dysfunction (1). In spite of increased experience of surgeons and advances in implant technology, prosthesis-derived infection remains as a serious adverse event (2). We present a case of necrotizing fungal penile infection after penile prosthesis implantation that resulted in total penectomy.

\section{Case Presentation}

Written informed consent was obtained from the patient. A 50-years-old male patient was admitted with the complaint of erectile dysfunction for 4 years. He had type 2 diabetes mellitus for 10 years and had been under insulin treatment for the last three years. International Index of Erectile Function score was 0 . He reported that previous treatments with phosphodiesterase type 5 inhibitors had been unsuccessful. His physical examination was normal.
The patient underwent malleable penile prosthesis implantation (Coloplast ${ }^{\circledR}$, Minneapolis, USA) via penoscrotal approach under perioperative vancomycin and gentamycin prophylaxis. The patient was discharged on postoperative $1^{\text {st }}$ day uneventfully.

At the postoperative $10^{\text {th }}$ day, the patient applied to our outpatient clinic with severe penile pain and hyperaemia in the incision line. Oral cefuroxime axetil $500 \mathrm{mg}$ twice daily and dexketoprofen $50 \mathrm{mg}$ once a day were initiated. However, ecchymosis and severe oedema occurred in the next 48 hours even after the oral treatment (Figure 1). Considering prosthesis-related infection, the patient was hospitalized and the prosthesis was removed same day. Tissue and drainage samples were obtained for antimicrobial culture study. As a "Trichosporon asahii" fungus was isolated in the culture, systemic antifungal (fluconazole $100 \mathrm{mg}$, twice a day) treatment was added. As patchy necrotic areas were observed at the glans penis, hyperbaric oxygen therapy was administered, however, necrosis spread despite antimicrobial and hyperbaric oxygen

Correspondence: Mehmet Gökhan Çulha MD, University of Health Sciences, İstanbul Training and Research Hospital, Clinic of Urology, İstanbul, Turkiye Phone: +90 5325620496 E-mail: gokhan_culha64@hotmail.com ORCID ID: orcid.org/0000-0003-4059-2293 Received: 13.08 .2016 Accepted: 03.10 .2016

Cite this article as: Çulha MG, Erkan E, Yücetaş U, Kadıhasanoğlu M, Toktaş MG. Necrotizing Fungal Infection Following Penile Prosthesis Implantation: A Case Report. J Urol Surg 2017;4:202-204. 
treatment. In 72 hours, the ischemia and necrosis increased till the base dominantly on the dorsal skin of the penis. The patient underwent penile amputation surgery.

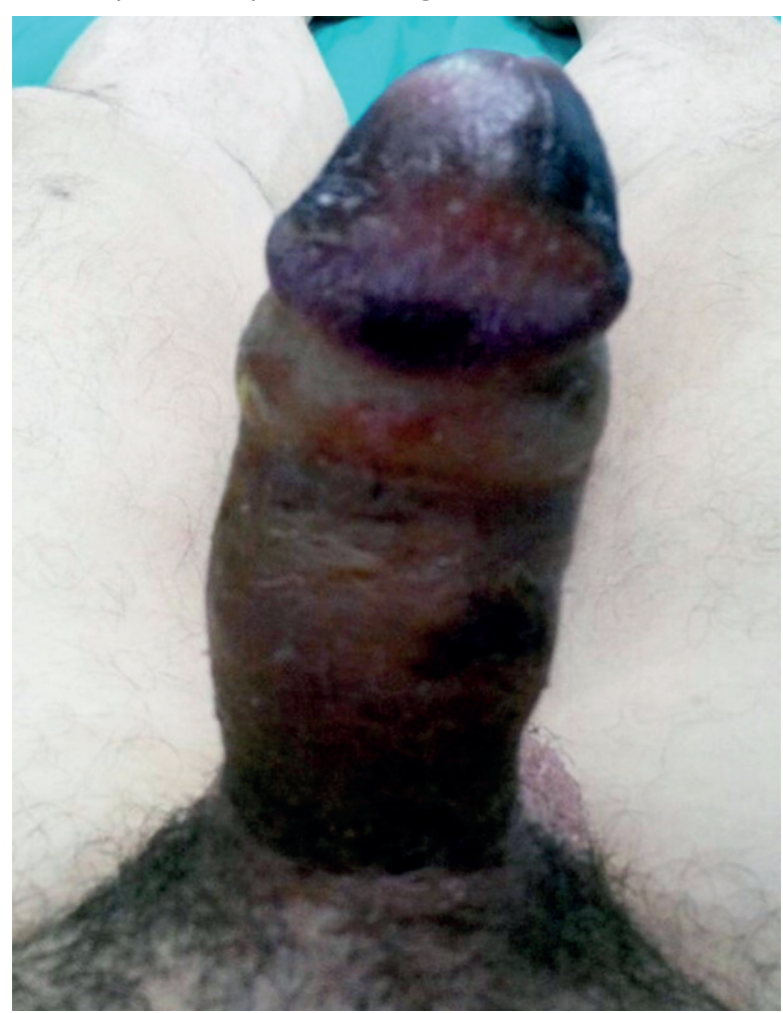

Figure 1. Necrotizing infection of the penis

\section{Discussion}

Penile prosthesis implantation is an effective and acceptable method for the management of organic erectile dysfunction (3). Infection is the most important complication of this procedure. Although the rates of infection have decreased in the past years; still, 1-3\% of cases suffer from this complication (4). The cost of a penile prosthesis infection has been shown to be six fold the original operation (5). Mulcahy and Carson (6) evaluated the rate of infection associated with penile prosthesis implantation in diabetic and non-diabetic patients. They demonstrated a significantly higher rate of infection in diabetic patients $(1.88 \%$ in diabetics vs. $1.53 \%$ in non-diabetics) (6).

Pathogens may contaminate implant via atmospheric exposure, unknown urinary tract infection or urethral injury during surgery, or via haematogenous or lymphogenous spread (7). The most common cause of infections is direct contact of the prosthesis with the skin flora during surgery. Coagulase-negative staphylococci are the most frequently isolated organisms from infected prostheses (5). The second most common infecting microorganism is Enterobacter aerogenes. Fungal infections have been described in approximately 5 percent of cases (5).
All humans are colonized as a commensal interaction with yeast and their virulence is related to the deterioration of host defense. The most common conditions for Candida proliferation include immunocompromised states, diabetes mellitus, antibiotic overuse, indwelling devices, and intravenous drug use $(8,9)$.

Trichosporon asahii and other members of the genus Trichosporon are basidiomycetous yeasts defined by the structure of true hyphae and pseudohyphae, arthroconidia, and blastoconidia (10). They have been isolated from soil and other environmental sources and from enclosed surfaces. In addition, they may be a part of the normal flora of the human skin, gastrointestinal tract and respiratory system (11).

An ideal treatment for Trichosporonosis has not yet been clearly defined (12). It has been recommended that antifungal drug resistance and high mortality rates seen in severe Trichosporonosis may be accomplished by the combination of two classes of antifungals (amphotericin B and fluconazole) (10). However, even after prompt and forceful antimicrobial treatment, it may not be sufficient to avoid catastrophic situations like local tissue necrosis leading to amputation.

Although a significant decrease in infectious complications has been accomplished in penile prosthesis surgery, these complications may still cause catastrophic outcomes. Although fungal infections are rarely seen after penile prosthesis implantations, surgeons must consider antifungal therapy if postsurgical infection does not ameliorate with antibiotic treatments, especially in patients with the poor host defense mechanisms.

\section{Ethics}

Informed Consent: Written informed consent was obtained from the presented case.

Peer-review: Externally peer-reviewed.

\section{Authorship Contributions}

Concept: M.G.Ç., Design: M.G.Ç., E.E., Data Collection or Processing: E.E., Analysis or Interpretation: M.K., E.E., Literature Search: U.Y., M.G.T., Writing: M.G.T., M.G.Ç.

Conflict of Interest: No conflict of interest was declared by the authors.

Financial Disclosure: The authors declared that this study received no financial support.

\section{References}

1. Pearman RO. Treatment of organic impotence by implantation of a penile prosthesis. J Urol 1967;97:716-719.

2. Carson CC, Mulcahy JJ, Harsch MR. Long-term infection outcomes afte original antibiotic impregnated inflatable penile prosthesis implants: up to 7.7 years of followup. J Urol 2011;185:614-618. 
3. Bettocchi C, Palumbo F, Spilotros M, Lucarelli G, Palazzo S, Battaglia M, Selvaggi FP, Ditonno P. Patient and partner satisfaction after AMS inflatable penile prosthesis implant. J Sex Med 2010;7:304-309.

4. Henry GD, Carson CC, Wilson SK, Wiygul J, Tornehl C, Cleves MA, Simmons CJ, Donatucci CF. Revision washout decreases implant capsule tissue culture positivity: a multicenter study. J Urol 2008;179:186-190.

5. Montague DK. Periprosthetic infections. J Urol 1987;138:68-69.

6. Mulcahy JJ, Carson CC. Long-term infection rates in diabetic patients implanted with antibiotic-impregnated versus nonimpregnated inflatable penile prostheses: 7-year outcomes. Eur Urol 2011;60:167-172.

7. Darouiche RO. Device-associated infections: a macroproblem that starts with microadherence. Clin Infect Dis 2001;33:1567-1572.

8. Peppas DS, Moul JW, McLeod DG. Candida albicans corpora abscess following penile prosthesis placement. J Urol 1988;140:1541-1542.
9. Cotta BH, Butcher M, Welliver C, McVary K, Köhler T. Two Fungal Infections of Inflatable Penile Prostheses in Diabetics. Sex Med 2015;3:339-342.

10. Li HM, Du HT, Liu W, Wan Z, Li RY. Microbiological characteristics of medically important Trichosporon species. Mycopathologia 2005;160:217225.

11. Walsh TJ, Melcher GP, Lee JW, Pizzo PA. Infections due to Trichosporon species: new concepts in mycology, pathogenesis, diagnosis and treatment. Curr Top Med Mycol 1993;5:79-113.

12. Fournier $S$, Pavageau $W$, Feuillhade $M$, Deplus $S$, Zagdanski AM, Verola 0 , Dombret $\mathrm{H}$, Molina JM. Use of voriconazole to successfully treat disseminated Trichosporon asahii infection in a patient with acute myeloid leukaemia. Eur J Clin Microbiol Infect Dis 2002;21:892-896. 